\title{
THE MINE TREMORS MECHANISMS RELATED TO THE DAMAGES IN MINE OPENINGS AND ON THE EARTH'S SURFACE.
}

\author{
Waclaw M. Zuberek, Ryszard Dubiel, Jolanta Pierwola, Bogdan Żogala. \\ University of Silesia \\ - Faculty of Earth Sciences \\ 60 Bedzinska Str. \\ 41-200 Sosnowiec \\ Poland
}

The catalogue of 10246 mine tremors from the Upper Silesian Coal Basin (USCB), Poland which occurred in the last 10 years (1987-1996) has been analysed. The seismic energies of analysed tremors were ranging from $1 \cdot 10^{5} \mathrm{~J}\left(\mathrm{M}_{\mathrm{L}}=1.76\right)$ to $2 \cdot 10^{9} \mathrm{~J}\left(\mathrm{M}_{\mathrm{L}}=4.03\right)$. The mine tremors are common manifestation of the dynamic deformation of the rock mass due to mining and there is no doubt that the majority of them is closely related to mining (e.g. breaking of roof rocks due to subsidence, roof caving, coal bumps) as a sudden release of stored elastic strain energy.

The frequency energy distribution of mine tremors shows typical hyperbolic form (table 1.) well known in seismology as Gutenberg-Richter frequency-magnitude distribution with coefficient $b$ which is typically close to 1.0 for different seismic regions over the world. This coefficient describes the ratio of small to large events in a given region and in a given time interval and more generally can be considered as a parameter controlling the rock mass capability of releasing accumulated elastic strain energy (Gibowicz and Kijko, 1994).

Table 1 Seismic activity of the USCB and number of coal bumps in 1987-1996 years.

\begin{tabular}{|c|c|c|c|c|c|c|}
\hline \multirow[b]{2}{*}{ Year } & \multicolumn{5}{|c|}{ Number of tremors with seismic energy $E_{s}$} & \multirow[b]{2}{*}{ Coal bumps } \\
\hline & $\begin{array}{c}\mathrm{E}_{8} \geq 10^{5}[\mathrm{~J}] \\
\left(\mathrm{M}_{\mathrm{L}}=1.76\right)\end{array}$ & $\begin{array}{l}E_{s} \geq 10^{6}[J] \\
\left(M_{L}=2.29\right)\end{array}$ & $\begin{array}{l}E_{s} \geq 10^{7}[\pi] \\
\left(M_{L}=2.82\right)\end{array}$ & $\begin{array}{l}E_{s} \geq 10^{8}[\mathrm{~J}] \\
\left(\mathrm{M}_{\mathrm{L}}=3.34\right)\end{array}$ & $\begin{array}{l}E_{s} \geq 10^{9}[\mathrm{~J}] \\
\left(M_{L}=3.87\right)\end{array}$ & \\
\hline 1987 & 2230 & 245 & 42 & 5 & 0 & 11 \\
\hline 1988 & 1594 & 127 & 14 & $\mathbf{0}$ & 0 & 13 \\
\hline 1989 & 1069 & 105 & 12 & 2 & 0 & 16 \\
\hline 1990 & 1038 & 78 & 7 & 2 & 0 & 16 \\
\hline 1991 & 856 & 42 & 4 & 1 & 0 & 9 \\
\hline 1992 & 763 & 60 & 7 & 1 & 1 & 10 \\
\hline 1993 & 929 & 93 & 11 & 5 & 2 & 17 \\
\hline 1994 & 739 & 79 & 7 & 1 & 0 & 12 \\
\hline 1995 & 466 & 81 & 10 & 2 & 0 & 7 \\
\hline 1996 & 497 & 65 & 11 & 0 & 0 & 2 \\
\hline All & 10246 & 975 & 125 & 19 & 3 & 113 \\
\hline
\end{tabular}


Fig. 1 Changes in seismic activity (A) [number of tremors per year], coal output (O) [t], released energy (E) [J] and b-value in 1987- 1996 years
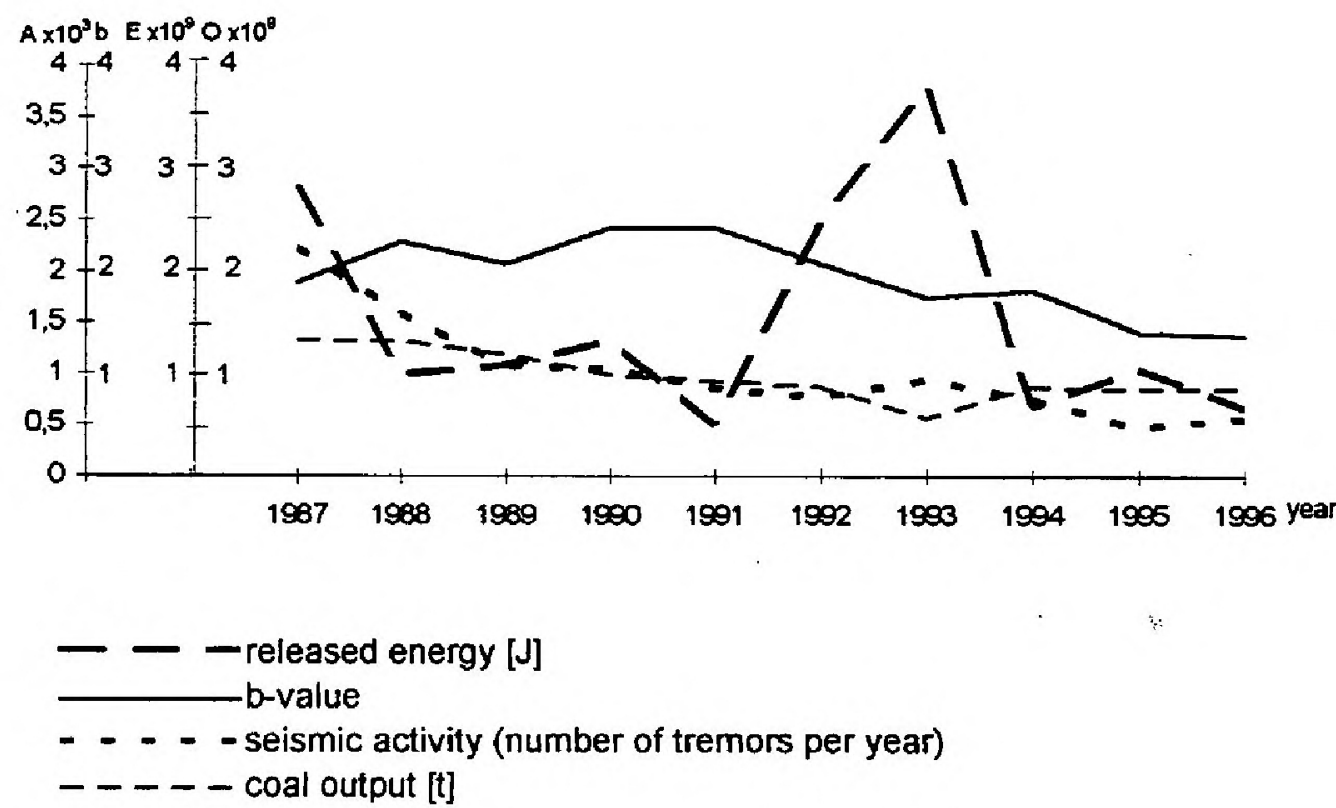

From the table 1 it is seen that seismic energy of tremors (constituting only very small percentage of the total released strain energy) ranges very widely. The reported damages in underground openings and accidents are usually connected with smaller energy of tremors because they depend on the critical state of the system, consisting of rock mass, the mine openings, their support and its ability of strain energy release. The numbers of reported damages and possible accidents underground (e.g. coal bumps) are much smaller than the total recorded tremors numbers. From extensive practice it has been established that while tremors with seismic energy $\geq 1 \cdot 10^{5} \mathrm{~J}$ can be felt by inhabitants only those with seismic energy $\geq 1 \cdot 10^{7}$ $\mathrm{J}\left(\mathrm{M}_{\mathrm{L}} \geq 2.8\right)$ may have negative impact on such environmental components as buildings, engineering facilities or natural objects.

Although the mine tremor magnitudes are much smaller than of severe earthquakes, when the tremor epicenters fall under the cities, the damages sometimes can be significant. As an example, reported damages due to some of the largest tremors in the area are specified in table 2 . The reported damages are usually not very severe but they depend on the actual state of the building and its construction.

Table 2 Some of the largest tremors in USCB with reported damages on the surface

\begin{tabular}{|c|c|c|c|c|}
\hline Date & $\begin{array}{c}\text { Magnitude } \\
\mathrm{M}_{\mathrm{L}}\end{array}$ & $\begin{array}{c}\text { Seismic energy } \mathrm{E}_{\mathrm{s}} \\
{[\mathrm{J}}\end{array}$ & Epicenter area & $\begin{array}{c}\text { Reported number of } \\
\text { damaged buildings }\end{array}$ \\
\hline $1989-06-30$ & 3.59 & $3 \cdot 10^{8}$ & Szombierki & 145 \\
\hline $1992-05-05$ & 4.03 & $2 \cdot 10^{9}$ & Bojszowy & 300 \\
\hline $1993-04-21$ & 3.87 & $1 \cdot 10^{9}$ & Miechowice & 10 \\
\hline $1993-12-09$ & 3.87 & $1 \cdot 10^{9}$ & Kochłowice & 140 \\
\hline
\end{tabular}


Quantity and severity of damage does not exclusively depend on tremor seismic energy (or magnitude) but also on the location of its epicenter, type of buildings, their dynamic impact strength and local geological conditions (amplification).

In spite of extensive underground coal mining carried out in almost the whole central part of the Basin the tremor epicenters are not uniformly distributed over the area and one can distinguish several regions of clustering. The courses of seismicity have been analysed for all the area of USCB and for selected structural units (in brackets the percentage share of overall seismicity is shown): main anticline, $(48 \%)$, Bytom syncline (18\%), main syncline $(16 \%)$, Jejkowice and Chwałowice synclines $(9 \%)$.

One can observe the decrease of seismicity related to the decrease of coal output and relatively well related to the corresponding changes of the $b$ value (Fig. 1). Lower $b$ values may indicate that even with lower seismicity in the area the capability of the seismic energy release has not been decreased and one can expect some larger events in the future.

The majority of tremors caused no damages on the surface and underground however the cause of damages for some of them is not quite clear. Therefore we have decided to analyse the focal mechanisms of selected tremors using the seismic moment tensor inversion method for P-wave first arrivals in time domain (Wiejacz, 1994) and compare the obtained solutions for tremors without reported damage, with well described underground damages (coal bumps) and with reported damages on the surface

The focal mechanisms were estimated on the basis of digital recordings from mine seismic networks. The seismic moment tensor completely characterises nine possible combinations of force and arm acting at the point source. The decomposition of the seismic moment tensor let us recognize the percentage share of:

- isotropic component (I) corresponding to volumetric change,

- compensated linear vector dipole component (CLVD) corresponding to uniaxial compression (or tension),

- double couple component (DC) corresponding to shear failure.

The mechanisms of the majority of the tremors in USCB consist of significant DC component and relatively small isotropic and CLVD components. There are also many tremors containing very small DC part and large isotropic and CLVD parts. The intermediate mechanism occur occasionally.

Table 3 Percentage share of the seismic moment tensor components of the 8 coal bumps and one tremor with reported damages

\begin{tabular}{|c|c|c|c|c|c|c|c|}
\hline $\begin{array}{l}\text { Epicenter } \\
\text { area }\end{array}$ & Date & $\begin{array}{c}\text { Seismic } \\
\text { energy } \\
E_{\mathrm{s}} \\
{[J}\end{array}$ & $\begin{array}{l}\text { Magnitude } \\
\mathrm{M}_{\mathrm{L}}\end{array}$ & $\begin{array}{c}\text { Isotropic } \\
\text { [\%] }\end{array}$ & $\begin{array}{c}\text { CLVD } \\
{[\%]}\end{array}$ & $\begin{array}{l}\mathrm{DC} \\
{[\%]}\end{array}$ & $\begin{array}{l}\mathrm{I} / \mathrm{D} \\
\text { ratio }\end{array}$ \\
\hline Wujek & 1993-05-25 & $8 \cdot 10^{5}$ & 2.24 & 19.2 & 18.6 & 62.2 & 0.24 \\
\hline Wujek & 1993-06-03 & $2 \cdot 10^{6}$ & 2.45 & 10.8 & 39.7 & 49.5 & 0.12 \\
\hline Wujek & 1993-09-11 & $8 \cdot 10^{7}$ & 3.29 & 43.9 & 40.7 & 15.4 & 0.78 \\
\hline Wujek & 1994-02-23 & $9 \cdot 10^{5}$ & 2.26 & 19.6 & 18.8 & 61.7 & 0.24 \\
\hline Wujek & 1994-04-15 & $2 \cdot 10^{6}$ & 2.45 & 21.5 & 20.5 & 57.9 & 0.27 \\
\hline Wujek & 1994-04-26 & $3 \cdot 10^{6}$ & 2.54 & 10.7 & 11.0 & 78.3 & 0.12 \\
\hline Halemba & 1994-01-12 & $2 \cdot 10^{5}$ & 1.92 & 33.6 & 38.7 & 27.7 & 0.51 \\
\hline Halemba & 1994-02-22 & $1 \cdot 10^{5}$ & 1.76 & 30.3 & 28.8 & 40.9 & 0.43 \\
\hline \multicolumn{4}{|r|}{ Average } & 23.7 & 27.1 & 49.2 & 0.34 \\
\hline Zabrze & 1997-05-01 & $1 \cdot 10^{6}$ & 2.29 & 30.3 & 29.6 & 40.1 & 0.43 \\
\hline
\end{tabular}


The table 4 shows average percentage share of particular seismic moment tensor components for the mine tremors of Halemba and Wujek coal mine areas. The energy range of the tremors is larger than $1 \cdot 10^{5} \mathrm{~J}$ and is comparable with coal bumps.

The solutions of the source mechanisms of 8 coal bumps are shown in table 3 .As one can see the mechanisms differ each other and one typical coal bump mechanism can not be determined.. For example the DC component varies from $15.4 \%$ to $78.3 \%$ of the total seismic moment tensor.

Table 4 Average percentage share of seismic moment tensor components of the mine tremors with energy larger than $1 \cdot 10^{5} \mathrm{~J}$

\begin{tabular}{|c|c|c|c|c|c|}
\hline Epicenter area & $\begin{array}{c}\text { Number of } \\
\text { events }\end{array}$ & $\begin{array}{c}\text { Isotropic } \\
{[\%]}\end{array}$ & $\begin{array}{c}\text { CLVD } \\
{[\%]}\end{array}$ & $\begin{array}{c}\text { DC } \\
{[\%]}\end{array}$ & I/D ratio \\
\hline Wujek & 24 & 26.83 & 25.14 & 48.05 & 0.37 \\
\hline Halemba & 57 & 22.94 & 16.18 & 60.88 & i \\
\hline \multicolumn{2}{|l}{ Total average (24+57 events) } & 24.09 & 19.83 & 57.08 & 0.36 \\
\hline
\end{tabular}

However comparing the mechanisms of the coal bumps with the typical mine tremors of the same energy range some differences can be noticed. The average CLVD component is about $7 \%$ larger and the average DC component is about $8 \%$ smaller for coal bumps whereas the isotropic component and I/D ratio (isotropic to deviatoric components) are similar (table 3,4 ). The increase of CLVD part and decrease of DC part of the seismic moment tensor could be related to mechanism of displacement of rocks into the mine openings during the coal bumps. Digital seismic networks (necessary for seismic moment tensor inversion) are not frequent in the USCB, so we collected the recordings of the only one mine tremor which caused the damages on the Earth's surface (up to now). The focal mechanism of the tremor (Zabrze 1997-05-01) is shown in the table 3. The tremor represents intermediate type of mechanism. The percentage share of particular seismic moment tensor components is close to each other and therefore this tremor differs from usually observed typical mechanisms of mine tremors.

\section{REFERENCES}

Gibowicz S.J., Kijko A., 1994: Introduction to mining seismology. Academic Press, San Diego.

Sagan G., Dubiel R., Mitrega P., Zuberek W.M., 1995: The mechanism of mining tremors related to damages observed in the stope area. Publ. Inst. of Geophys., Pol. Acad. Sc., Vol. M-19 (281), Warsaw, 31-45 (in Polish)

Wiejacz P., 1994: SMT computer software (unpublished) 